Final draft - cite published version available at Taylor \& Francis Online:

Luke William Hunt (2020) Hobbesian causation and personal identity in the history of criminology, Intellectual History Review, DOI: 10.1080/17496977.2020.1738761

\title{
Hobbesian Causation and Personal Identity in the History of Criminology
}

\author{
Luke William Hunt \\ University of Alabama
}

\begin{abstract}
Hobbes is known for bridging natural and political philosophy, but less attention has been given to how this distinguishes the Hobbesian conception of the self from individualist strands of liberalism: First, Hobbes's determinism suggests a conception of the self in which externalities determine the will and what the self is at every moment. Second, there is no stable conception of the self because externalities keep it in a constant state of flux. The metaphysical underpinnings of his project downplay the notion of a purely individualistic conception of the self, pointing to a positivist theory of criminology relying upon external forces. This theory is especially prescient with respect to twentieth century variants of positivism that focus upon how social organization affects personality. In a sense, then, modern criminological theory is indebted to Hobbes's focus upon the connections between externalities and the self - a focus that illuminates new ways of viewing responsibility and accountability.
\end{abstract}

Key words: [Hobbes, liberalism, causation, personal identity, determinism, criminology]

The political philosophy of Thomas Hobbes has become intertwined with a variant of liberalism associated with an exceedingly individualistic conception of the self. ${ }^{1}$ To put it less anachronistically, one might describe this as a conception of the psychological mechanisms of personal identity - though "self" may be used as shorthand. Although it is an imprecise conception, the idea is roughly that one's volition may be imposed on the world unimpeded by externalities. It is easy to see how Hobbes's political philosophy came to be associated with this view. With some obvious justification, Hobbes's political theory is typically set against the backdrop of a form of psychological egoism that interprets one's conceptual framework as mere individual preference. ${ }^{2}$ For example, Hobbes's state of nature (or "the condition of mere nature") can seem to suggest a bare subject from whom the multitude of personal, institutional, and cultural influences may be stripped, leaving behind a subject concerned solely with self-interest. It is in part this picture of the self that allows Hobbes to derive his institutional political principles. In some respects, this picture is undeniably accurate because Hobbes promotes it unambiguously. But these superficial aspects of Hobbes's political philosophy do not tell the whole story. It is also the metaphysical underpinning of Hobbes's systematic project that is vital to his conception of the self in both natural and political philosophy. ${ }^{3}$ This paper examines how Hobbes's account of the metaphysics of causation is at odds with the conception of a detached self that is often associated with his political theory. The examination of this issue will lead to some interesting conclusions, including a novel interpretation of Hobbes's theory of criminology that situates him closer to the positivist school.

Hobbes is typically viewed as a forerunner of the "classical school" of criminology, which justifies punishment based upon the presumption that it deters rational agents who act freely. ${ }^{4}$ The positivist school manifests itself in a variety of forms, but generally responds to the classical school with "scientific" (or positive) explanations (e.g., social) of crime. ${ }^{5}$ It is easy to see why Hobbes is more closely associated with the classical school. Hobbes's conception of human beings as largely egoistic, equal, and rational lays the groundwork for social contract (or "covenant") theory (with an enforcer to protect one's self-interest) and the classical school's justification for punishment. ${ }^{6}$ Although this paper does not suggest that the standard view should be upended, it does show how it needs to be reoriented. Before reaching this payoff, though, a fair amount of legwork must be conducted regarding the relationship between Hobbes's political philosophy and his natural philosophy. The idea that Hobbes's political philosophy is grounded broadly in natural philosophy is of course not new. ${ }^{7}$ The focus here will thus be on a narrower topic: the extent to which Hobbes's stance on causation and determinism suggests a more diverse conception of the self than the exceedingly individualistic conception typically 
associated with his philosophy. The goal, then, is to show how Hobbes's position on causation sheds light on a more multidimensional and interconnected view of the self .

Recent work by Sharon Lloyd, Samantha Frost, and others is suggestive of this goal, particularly Lloyd's account of "transcendent interests" in Hobbes's work and Frost's account of how Hobbes's materialism implies a self that is "always embedded in and a part of a collective." 8 This paper builds upon such conceptions of the Hobbesian self, while presenting a novel argument centered on two themes: (1) Hobbes's determinism opposes a conception of the self from which one may detach all externalities because those externalities necessarily determine the will and what the self is at any given moment, and (2) there is no stable conception of the self that persists because the externalities at play on a subject keep the self in a constant state of flux. The resulting conclusion is that Hobbes's political philosophy - as based upon his natural philosophy - situates his criminological theory more closely to the positivist school, which may illuminate new ways of viewing responsibility and accountability.

\section{Classical and Positivist Criminology, Rational and Material Agency}

Given that Hobbes is often viewed as an early representative of the classical school of criminology, it is helpful to lay the groundwork with a very brief history of that school and its evolution in contemporary political philosophy - as well as a brief comparison with the positivist school. This will help show that while Hobbes's work is undoubtedly tied to the former, it also includes important connections to the latter.

\section{Classical Criminology and the Liberal Tradition}

"Criminology" typically refers the study of crime, the causes of crime, and the way that a polity treats (and should treat) offenders. Contemporary criminology also includes specific theories of criminal behavior, law, and justice - such as "strain" (the theory that limited legitimate economic opportunity in societies that value economic success leads people to commit crimes) and "social disorganization" (the theory that one's locale affects one's criminal proclivities given that some communities are unable to come together to solve problems). "Classical" criminology is associated with the Enlightenment of the eighteenth and nineteenth centuries because it emphasizes human reason, value, and agency. The emphasis on such values can be contrasted with earlier and harsher treatment of offenders that was based upon arbitrary state action and authority. Accordingly, a central component of the classical school is the relationship between persons and the state given one's capacity to be party to the social contract. In other words, persons who rationally and voluntarily submit to state authority -in exchange for certain common goods from the state - are subject to punishment if they break the state's rules grounded by the social contract. Prominent classical theorists include Jeremy Bentham and Cesare Beccaria. Hobbes is included among this group because the classical school emphasizes one's criminal responsibility given one's rationality and freedom to engage in right and wrong acts.

Let us consider how the classical model fits in with contemporary theories of justice in the liberal tradition. Theories of justice in the liberal tradition often begin with an assumption (some would call it a platitude) that all persons have the capacity to be free and equal. This pre-political conception of persons extends through the Enlightenment, famously forming the foundation for many modern states and serving as the basis of prominent contemporary theories of justice. As I have noted elsewhere, "the rudiments of this idea can be grasped by examining how desert-based legal institutions account for actions and accompanying mental states with an explanation that is based upon a conception of the person as having the capacity [...] for these natural properties (rather than an explanation based upon any particular metaphysical conception)." Rawls puts it this way: "in virtue of their two moral powers (a capacity for a sense of justice and for a conception of the good) and the powers of reason (of judgment, thought, and inference connected with these powers) persons are free." ${ }^{\prime 10}$ Accordingly, if the state ascribes to persons the capacity to act voluntarily, the upshot is that it would be morally wrong for the state to hold one responsible for acts that do not conform to the commonsense psychology invoked by the state. ${ }^{11}$ Conceiving of persons as "equal" is typically treated as a corollary of conceiving of persons as free: Persons are equal inasmuch as they have the capacity to possess the natural properties that allow for a commonsense psychological understanding of their culpable behavior."12 


\section{Positivist Criminology and Materialism}

Positivism developed in the late nineteenth century, responding to many of the basic tenets of the classical school. One of the central components of positivist criminology is the goal of furthering "scientific" approaches that treat criminal activity as a social phenomenon. Unlike the classical school, then, positivist criminology downplays the significance of free will to criminal behavior. Positivism instead emphasized the relationship between biological, psychological, economic, and social forces and a person's propensity to engage in criminal acts. Early positivist criminology manifested itself in a variety of ways by a variety of theorists. Adolphe Quetelet argued that crime had biological and societal causes based upon three broad categories: accidental (e.g., wars, famines), variable (e.g., personality), and constant (e.g., age, gender, occupation), while Cesare Lombroso's notorious work includes theories of the "born criminal." 13 Of course, positivism evolved into more rigorous methods of quantitative science that has occupied much of twentieth- century criminology. As we will see, the "Chicago School" was a manifestation of positivism that examined how externalities (social organization) affected personality (or the what might be described as the "self"). It is here that we find surprising connections to Hobbes.

\section{The Convergence of Rational and Material Agency in Hobbes}

There are several broad insights regarding the relationship between Hobbesian agency and materialism in Sharron's Lloyd's illuminating work. Her Ideals as Interests in Hobbes's Leviathan reorients and embeds Hobbes's conception of human nature and personal identity historically - within religion, politics, and education, for example. ${ }^{14}$ In other words, the idea is that Hobbes sets forth an empirical conception of social disorder rather than a simplistic conception based merely upon natural philosophy. Lloyd writes: "Hobbes took social disorder to be primarily the result of actions on transcendent interest [... that are] systematically disruptive." These interests - such as religious interests - lead to disorder and are the result of "actual existing social practice." 15 Accordingly, a central facet of Lloyd's argument is that Hobbesian human nature is in large part based upon sociological questions and concerns. ${ }^{16}$ Already, then, we can begin to see how Hobbesian criminology might be reoriented toward positivism. Answers to social disorder thus have less to do with crudely conceived notions of an isolated "self," and more to do with deconfliction of transcendent social interests through education and a principle of political obligation. ${ }^{17}$ This highlights the balancing role of rationality, with Lloyd suggesting that Leviathan is in large part about addressing social disorder by providing reasons (such as prudential, moral, and religious reasons) for political obligation. ${ }^{18}$

Lloyd's Morality in the Philosophy of Thomas Hobbes complements many of these themes, setting forth what she describes as the "reciprocity theory of reason" for political obligation. ${ }^{19}$ The basic idea yields an interpretation of what it means to be a rational animal, namely: beings who act on practical reasons. ${ }^{20}$ According to Lloyd, the basis of such reasons is whether (1) the reason would serve as a reason for the actions of others, and (2) the actual attitudes of agents. ${ }^{21}$ For present purposes, the takeaway from Lloyd's interpretation is the idea that rational agents desire to justify themselves to others a social component of human psychology - in their pursuit of transcendental concerns and social order.

Variations of these themes are apparent in more recent work regarding the relationship between Hobbesian agency and materialism. Arash Abizadeh suggests that Hobbes's conception of voluntary action is not merely a limited cognitive process, but also includes linguistic reasoning. The upshot is that Hobbes's account of agency emphasizes a connection - through linguistic reasoning - between materialist determinism and a cognitive conception of deliberation and voluntary action. ${ }^{22}$ In other words, there is a robust convergence of the rational and the material for Hobbes. As Abizadeh puts it, Hobbes's goal is "to provide a materialist, determinist account of reasoning, reason-responsive agency, and voluntary action that, by appealing to the artifice of language, bypasses any appeal to an incorporeal will or intellect and relies instead on the same faculty by which we perceive, imagine, and remember." 23 This suggests the causal component in Hobbes's theory, which I give a more detailed treatment in the next section. Here, though, note how Abizadeh describes Hobbes as developing his materialist, determinist account of reasoning "by characterizing responding to reasons as a causally determined activity in which agents form beliefs on the basis of rules for inference embedded in linguistic 
conventions." ${ }^{24}$ This line of thought will ultimately help support an interpretation of Hobbesian criminology evoking positivism.

In a similar way, Sandra Field has described a Hobbesian science of politics based upon a conception of persons as material bodies subject to mechanical forces that is compatible with a conception of persons as moral subjects who appeal to reason. ${ }^{25}$ Field's focus is the materialist prong of Hobbes's project. She suggests that if a Hobbesian science of politics entails agents who appeal to reason, "it must be compatible with the analysis of human beings as potentially irrational material bodies [...] in a web of causal relations [...]." ${ }^{26}$ Like Field, I draw out support for this line of thought in the context of both Leviathan and De Corpore in the next section. The hope is that this will help lay the groundwork for a socially embedded, casuist version of Hobbesian criminology. Interestingly, we will see how this account of Hobbesian criminology shares some aspects with contemporary liberal theory, while departing from strictly rationalistic interpretations.

\section{Hobbesian Causation}

As was seen from Abizedah and others, Hobbes's materialism shapes his account of deliberation. More broadly, the Hobbesian account of the metaphysics of causation serves as a basis of a unified philosophical project that yields a conception of the self that is intertwined in a web of externalities. This is apparent in several key passages from Leviathan, which suggest a bridge between Hobbes's natural philosophy and his political philosophy. These passages focus upon the related concepts of liberty, power, necessity, and freedom. Although the way that Hobbes uses these concepts to connect natural and political philosophy is important, the focus in this section is upon the way his determinism intricately connects one to one's environment and others. This notion is reaffirmed by Hobbes's taxonomy of causation in De Corpore, particularly regarding the relationship between agents and patients and the implications of that relationship. ${ }^{27}$ Ultimately, these texts help show that what is rational in human behavior is shaped by the material and social context. As we will see, the upshot is a synthetic middle point between the classical and the positivist schools of criminology.

\section{Causal Chains in Leviathan}

There are several places in Hobbes's systematic project at which one might identify a connection between natural and political philosophy. One of the more obvious jumping-off points is Hobbes's argument regarding liberty in Chapter 21 of the Leviathan. Hobbes treats the terms "liberty" and "freedom" synonymously here, with each meaning the absence of external impediments of motion. Hobbes makes use of this conception of liberty strictly, applying it to rational, irrational, and inanimate things alike. Under the narrow framework of external impediments of motion, then, a person, a snail, and a rock may all possess liberty. However, Hobbes does distinguish external and internal impediments of motion. While the former relates to a thing's lack of liberty, the latter relates to a thing's lack of power. This means that the impediment of motion is derived from the thing itself: a stone at rest lacks the power to move, as does one who is confined to bed because of sickness. These examples of internal impediments nevertheless reinforce Hobbes's strict materialism. Although they are deemed internal impediments, they continue to focus exclusively on a thing's motion rather than some sort of internal psychology or weakness of the will.

Indeed, Hobbes argues that it is incorrect to apply terms such as "liberty" and "free" to anything other than bodies because only bodies are subject to motions and impediments of motion; moreover, we cannot conceive of the existence of anything that is not body ${ }^{28}$ Describing a free will is thus nonsensical for Hobbes; instead, we may only describe a free man: "He, that in those things, which by his strength and wit he is able to do, is not hindered to do what he has a will to." ${ }^{29}$ Tying together natural philosophy and political philosophy in this way has dramatic implications, of course. For instance, Hobbes must acknowledge that one acts with liberty even if one's act is performed out of fear, illustrating this point with the famous example of a man who is forced to throw his goods overboard in order to save his ship from sinking. Such a man acts with freedom and liberty because nothing impedes his action of throwing the goods overboard. ${ }^{30}$ This rigidity in Hobbes's stance on liberty raises obvious questions regarding one's political liberty, freedom, and consent to political obligations in a political 
society. ${ }^{31}$ Although describing liberty as freedom of motion does not seem to be a complete conception of what it means to have liberty in a political context, Hobbes fills in this conception in other ways.

The above points present a strong materialistic connection between Hobbes's natural philosophy and political philosophy. More importantly, they lay the groundwork for Hobbes's view that liberty and necessity are compatible, and it is the nature of this compatibility that points toward the notion that Hobbes's conception of the self is uniquely interconnected to externalities. Hobbes first argues that one's voluntary actions proceed from liberty because they proceed from one's will. He then introduces the idea of necessity: "every act of man's will, and every desire, and inclination proceedeth from some cause, and that from another cause, in a continual chain, (whose first link is in the hand of God the first of all causes)." ${ }^{\prime 3}$ This picture of necessity suggests that one is inextricably intertwined with the multitude of things that determine not only one's every action, but also one's every inclination and desire. Although one's voluntary actions and inclinations may proceed from liberty and one's will, they also each result from a complex web of causes. Neither this web of causation nor the necessity of our actions is apparent to us. ${ }^{33}$ Such an account of causation raises basic questions for Hobbes regarding the compatibility of liberty and necessity. This issue will come up again in the next section, but for now the important point is the internal-external interdependence that Hobbes ascribes to the self.

Consider the conception of voluntary motion introduced above. In Chapter 6, Hobbes describes two sorts of motion in a person. The first sort includes involuntary bodily functions, such as breathing. The second is voluntary motion, which includes speaking and moving one's body in the way the mind desires. Although a person's voluntary actions may be the result of a series of elaborate causal chains, the initial cause of voluntary motion is something internal within a person, namely, the imagination: "And because going, speaking, and the like Voluntary motions, depend always upon a precedent thought of whither, which way, and what; it is evident, that the Imagination is the first internall beginning of all Voluntary Motion.. ${ }^{34}$ Establishing imagination as the initial internal cause of voluntary motion means that the Hobbesian self is not static, but rather dynamic and in constant flux due to its engagement with the environment: "Because the constitution of a mans Body, is in continuall mutations; it is impossible that all the same things should always cause in him the same Appetites, and Aversions." 35

As seen from the preceding passages, the imagination is the initial cause of voluntary motion, but the imagination may be prompted by external causes. Hobbes calls the internal beginnings of voluntary motion appetite when those internal beginnings are directed toward an external cause. While some appetites are innate (e.g., the desire for food), many are the result of particular experiences; these experiences are of course diverse and affect one's appetite accordingly. It is here that one can begin to see the interconnection between a person's internal and external causal chains. Although causal chains are never fully internal (they are determined by externalities), there is a dynamic interplay between one's imagination and one's environment. Against the backdrop of Hobbes's determinism, then, the self is in a perpetual evolution as a result of the complexity of both the external and internal causal chains in play. The picture Hobbes presents is that the self may not be detached from people, institutions, practices, and so on, that make up the external causes that inevitably act upon and shape one's internal constitution. The final pages of Part II (Of Common-wealth) in the Leviathan, make the point succinctly: "There is no action of man in this life, that is not the beginning of so long a chain of Consequences, as no humane Providence, is high enough, to give a man a prospect to the end." ${ }^{36}$

\section{Agents and Patients in De Corpore}

Hobbes's analysis of cause and effect in De Corpore - particularly his account of the relationship between agents and patients - expands upon the notion developed in Leviathan that the self is intimately tied to externalities. It is important to first clarify the structure Hobbes uses in his treatment of causation. Bodies act on other bodies when they do something to other bodies, such as when Body 1 encounters Body 2 and generates motion in Body 2. Such action thus involves two concepts: Body 1 is the agent because it generates motion in Body 2, and Body 2 is the patient because it is the body in which motion is generated by Body 1. The motion generated in Body 2 is the effect. However, Hobbes does not describe the cause of such effects in terms simply of the agent, but rather in terms of particular accidents that are unique to both the agent and patient involved in a cause and effect relationship. In other words, there are innumerable factors - or accidents - that are requisite in both the agent and the patient in order for any particular effect to occur (causa sine qua non). ${ }^{37}$ The "entire cause", then, consists of all the 
accidents in both the agent (efficient cause) and the patient (material cause), and the upshot is that when all accidents are present "it cannot be understood but that the effect is produced at the same instant; and if any one of them be wanting, it cannot be understood by that the effect is not produced." ${ }^{38}$ This point especially helps show how external contingencies play a necessary role in determining the self. In a sense, then, a conception of the self that is detached from external contingences is at odds with Hobbes's metaphysics.

Finally, let us consider Hobbes's notion of necessary causes in De Corpore. Recall that in the Leviathan Hobbes's view of necessity means that one is intertwined with a multitude of externalities that set the course for one's actions, inclinations, and desires. In other words, one's voluntary actions and inclinations proceed from the will, which is determined by a web of causes beginning with God. Hobbes's account of necessary causes in De Corpore provides additional support for the compatibility between liberty and necessity. Building upon the above account of entire causes, Hobbes argues that an effect is produced in the same instant a cause is entire. Therefore, a necessary cause is a cause that must be followed by the relevant effect. So, again, all effects occur necessarily because they are derived from an entire - and thus necessary - cause. Importantly, however, Hobbes describes this notion of cause and effect as a perpetual evolution between agents and patients: "There is a continual mutation in the agent or agents, by the working of other agents upon them, so also the patient, upon which they work, is continually altered and changed." 39 Here again we see the complex - and necessary - interplay between agents and patients, bodies and externalities. For Hobbes, then, it is sufficient to say that one acts with liberty if one is not impeded from voluntary action. The fact that these actions are intricately tied to a web of necessary internal and external causes is not problematic, but rather a natural result of the way Hobbes views one's connection to the world. ${ }^{40}$

One can glean a few important points from this sketch of Hobbes's account of the metaphysics of causation. First, there is seemingly a bridge between Hobbes's natural philosophy and his political philosophy, particularly in the context of liberty and necessity. To be sure, it is common (though not uncontroversial) to say that Hobbes was engaged in a systematic project of deriving the principles of political philosophy from those of natural philosophy. For example, David Gauthier described Hobbes's approach to achieving a unified science as follows: "We resolve, or as Hobbes often prefers to say, analyze a whole - a watch, or a commonwealth - into its constituent parts, discovering the relations among the parts, which then enable us to recompose or synthesize the whole." ${ }^{41}$ So while this interpretation of Hobbes is not unique, the actual theory put forth by Hobbes is. Linking natural philosophy and political philosophy is a decidedly novel approach that requires a decidedly large commitment from Hobbes. In many ways, his natural philosophy and his political philosophy stand and fall together because they are two parts of a bigger whole. ${ }^{42}$ One may not detach fundamental aspects of Hobbes's conception of the self without compromising Hobbes's entire project. As a systematic, unified project, one must take Hobbes's conception of the self as it is the world, namely, inextricably intertwined in the web of externalities that form the basis of his theory of causal determinism. In De Corpore, this account is affirmed by the interplay between agents and patients. And though this account of the self may not always be as obvious in his representational device - the state of nature - it is no less relevant. The next section examines how this account of causation is at odds with many aspects of an individualistic strand of liberalism, while remaining consistent in unexpected ways.

\section{Determinism and the Self in Hobbes's Political Theory: A Path to Positivist Criminology}

In light of the many interpretative threads noted in the literature (Abizedah, Field, Frost, Lloyd, and so on), one can draw a broad conclusion about the relationship between Hobbesian agency and causation in his natural philosophy: rational autonomy and determinism are not polar opposites. To say that Hobbes is a determinist is not to say that a lack of freedom equates to a lack of autonomy. This is because freedom and necessity are in a sense bound together. Accordingly, it is in a sense more apt to describe the Hobbesian self through the idea of heteronomy. In other words, the Hobbesian self develops and becomes manifest through complex webs of causation - influences outside the self. The upshot is a socially embedded self that shares attributes of a more casuist version of Rawls - rather than a strictly rational, proto-classical criminologist. 
There are several examples that help draw out these points. For example, Hobbes's state of nature does not yield a conception of the self that is a bare subject from whom the multitude of external influences may be stripped, leaving behind a clear picture of a subject concerned with self-interest solely. This is of course different from various forms of contemporary liberalism, including some interpretations of liberalism associated with Rawlsian political philosophy. However, while Hobbes's theory suggests a more collective and social conception of the self, it retains similarities to liberalism that are drawn out in the work of Lloyd, Frost, and others. And this conception of the self helps establish a connection to the positivist school of criminology

\section{The Condition of Mere Nature}

In Leviathan, the aim of Hobbes's political philosophy project is to provide an account of a secure society for individuals, "the conservation of Peace and justice, the end for which all Common-wealths are Instituted." ${ }^{43}$ His technique for providing such an account has by now become a paradigm of political philosophy. In order to get his theory off the ground, Hobbes's uses a hypothetical device the state of nature - to show how and why individuals would form a civil society. Although he is clear that it is a hypothetical device ("there had never been any time, wherein particular men were in a condition of warre one against one another"), it is important to note that Hobbes does indeed compare the state of nature to actual places with actual people: "there are many places, where they live so now [...] the savage peoples in many places in America, except the government of small Families, the concord whereof dependeth on natural lust, have no government at all; and live at this day in the brutish manner, as I said before." ${ }^{44}$ This is an important point because it at least minimally anchors Hobbes's state of nature to the actual world, and it thus anchors the hypothetical individuals in the state of nature to actual individuals in the actual world. In other words, Hobbes's account of the abstract individuals who inhabit the state of nature is not necessarily as abstract as one might think; instead, they are comparable to actual people who inhabit actual places.

Although Hobbes famously describes one in the state of nature as living in "continuall feare, and danger of violent death; And the life of man, solitary, poore, nasty, brutish, and short," he does not suggest that we must imagine an abstract conception of the self, unencumbered by external influences, in order to derive the principles of society. ${ }^{45}$ Indeed, Hobbes specifically mentions the existence of common ties, influences, and obligations, in the state of nature, namely, those that are familial and sexual in nature. It is by no means clear, then, that we are to imagine the self in Hobbes's state of nature in a wholly detached, individualist manner. ${ }^{46}$ Instead, the most we can say is that Hobbes's state of nature is a very unpleasant place, one in which people not unlike ourselves would be motivated to form a civil society.

In addition to familial connections, religious ties prevent the Hobbesian self in the state of nature from being conceived as an abstractly individualistic conception. In Chapter 10 of Leviathan, Hobbes notes several ways in which one may honor another, all of which are available without the existence of a commonwealth. ${ }^{47}$ Shortly thereafter, in Chapter 12 , Hobbes expands upon this theme by describing religion as something inherent in the self: "the first seeds [of religion ... ] can never be so abolished out of human nature, but that new Religions may againe be made to spring out of them, by the culture of such men, as for such purpose are in reputation." 48 So while new religions may develop from the culture of a civil society, religion is a part of Hobbes's state of nature; presumably, it is something that one embraces or rejects according to the causal chains that shape the self. Hobbes develops the point more explicitly in Chapter 14, where he describes how religion can elicit fear in one even if no civil society exists: "The Feare of [... God] is in every man, his own Religion: which hath place in the nature of man before Civill Society." 49 Familial and religious ties cannot be sensibly detached from the self, neither in a hypothetical state of nature nor in other contexts.

This makes sense considering his views on causation discussed earlier. A person is tied to complex causal chains, both internal and external, that form the basis of the self. It would thus seem odd to characterize the Hobbesian conception of the self in the state of nature as a freestanding, individualist ideal that may be abstracted away from externalities. In one sense, this is because such externalities are constitutive of the self in that they determine one's will. Jurgen Overhoff has made a similar point, noting that for Hobbes the "motions of external objects working on our nerves and brain [...] produce conceptions or motion in some internal substance of the head." ${ }^{50}$ In other words, one is unable to engage 
one's will without those necessary externalities. And this means that one cannot abstract away the history of the self because that history determines what the self is at any given moment.

Nevertheless, Hobbes's use of the state of nature to develop his political philosophy bears many obvious resemblances to the liberal individualism of contemporary political philosophy, particularly Rawls's use of the original position. This can be illustrated with a few brief examples, which also help draw out how the crucial differences are in the details. Consider how Rawls describes his aim in the opening pages of $A$ Theory of Justice: "to present a conception of justice which generalizes and carries to a higher level of abstraction the familiar theory of the social contract." ${ }^{, 1}$ Although he does not refer to Hobbes as one of the sources for this tradition (he does refer to Locke, Rousseau, and Kant), Rawls's hypothetical device for establishing the principles of justice - the original position - is of course explicitly based upon the state of nature: "the original position of equality corresponds to the state of nature in the traditional theory of the social contract." ${ }^{52}$ The hypothetical original position is thus designed to replicate the state of nature so that one may derive the principles of justice that would be selected as the basis of civil society. The parties in the original position are famously situated behind a veil of ignorance so that the principles of justice are based on fairness, rather than attributes that are the result of "natural chance or the contingency of social circumstances." ${ }^{33}$ This point is crucial because Rawls is far more explicit regarding what he detaches from the self in the original position. ${ }^{54}$

What this means is that one of the predominant, contemporary, liberal conceptions of the self is in a sense at odds with the conception of the self in Hobbes's hypothetical state of nature. This is because the self in Rawls's original position would for Hobbes be too detached from externalities to justify the output of the original position. In other words, to conceive of the self - even in a representational device such as the original position - abstracted away from the causal chains that necessarily determine one's will would leave behind a self that was incapable of willing the output (the principles of justice) of the original position. Now, this does not mean that it would have been impossible for Hobbes to conceptualize a representational device such as the veil of ignorance. To be sure, Hobbes's mechanical conception of the self does not rule out the possibility of counterfactual accounts of one's choices and how those choices might have affected one differently. The point is a much less controversial claim about the Hobbesian self. Although it is certainly possible to conceive of a Hobbesian self without conceiving of all the particular external causal chains (one would be unaware of many such chains and their causal role), it is not altogether sensible to abstract away all such chains because they are fundamental in determining the will and the self. To do so would mean that it would be unclear exactly what Hobbsian self one was conceiving of because there would exist no persisting, stable, atomistic ideal. Moreover, Hobbes's larger, systematic project would be severely weakened in that there would no longer be a consistent, scientific account of the self that is intertwined with complex internal and external causal chains.

That said, the ultimate goals of Hobbesian and contemporary political philosophy are undoubtedly similar in many ways. For example, Rawls cites Leviathan as containing the thesis behind his notion that a coercive sovereign is necessary because "the existence of effective penal machinery serves as men's security to one another." ${ }^{55}$ More generally, Richard Tuck's recent chapter, "Hobbes and democracy," positions Hobbes's political theory as a forerunner of democratic political ideals. ${ }^{56}$ These ideals - which might include equal natural rights and liberties and an account of civil society that invokes hypothetical devices - place Hobbes unmistakably in the liberal tradition. But while the big picture may be similar, the details of the hypothetical parties that yield an account of civil society remain inconsistent in many ways.

To suggest, for instance, that both the state of nature and the original position rely upon the judgment of individuals who are presumed not to know many facts about themselves and their actual circumstance (such as religion) would be at odds with what we have seen in Leviathan. ${ }^{57}$ Familial and religious ties, conceptions of honor, and a generally complex interplay between a subject and his world are all present in Hobbes's state of nature - a hypothetical device populated by hypothetical representatives that Hobbes nonetheless compares to actual people and places. Although this is perhaps a minor point when viewed in isolation, it is more significant when considering how it shows that Hobbes's state of nature is far from a carbon copy of contemporary conceptions (especially Rawls's original position behind the veil of ignorance). For example, interpretations that view the Hobbesian self as more isolated from externalities strike a fatal blow to Hobbes's larger, systematic project, which includes a scientific account of the self that is intertwined with complex internal and external causal chains. In short, while 
Hobbes's state of nature shares some similarities with representational devices such as the original position, it seems clear that Hobbes does not intend to detach externalities from the self in a contemporary, Rawlsian way. Instead, the vivid descriptions of the state of nature ("solitary, poore, nasty, brutish, and short") seem to be more about rhetorical flare - a richly suggestive metaphor regarding the necessity of a sovereign.

\section{Transcendent Interests, Criminology, and the Hobbesian Self}

Recall the earlier discussion of "transcendent interests" in Lloyd's work - especially how Lloyd suggests that social disorder is a result of such interests. These are socially embedded interests (religion, for example), which are so important to one's self identity that one would sacrifice more basic interests (such as personal safety). And this may result in social disorder, lending support to the view that Hobbesian criminology should in part be viewed through the lens of positivism's social framework The upshot is that Hobbesian criminology includes the connection between social disorder and socially embedded interests - not a simplistic notion of rational agents focused on mere self-preservation by avoiding state punishment. The Hobbesian self is much more complex given the role of transcendent interests articulated in Lloyd's work. Coupled with Hobbes's natural philosophy, the self is a conflux of social chains that include religion, education, rationality, and so on - all of which contribute to transcendent interests and social disorder. Hobbes's natural philosophy is thus the anchor that yields a conception of the self that is prescient with respect to positivistic criminology. And it is a compatibilist theory in which the determinism of the natural philosophy does not negate one's agency.

This interpretation stands to reason inasmuch as positivism implies that the self is defined by a multitude of collective and communal connections, without which it would be no longer possible to conceive of a particular self. The connection to Hobbesian causation is apparent given that we have seen how Hobbes suggests a self that is defined by communal, familial, religious, and other externalities that may not be detached from a subject. The first thing that one may take away from this conclusion is that Hobbes's conception of the self is less in line with an individualistic conception prominent in some variations of liberalism. ${ }^{58}$ In any event, Hobbes's conception of the self in the state of nature is consistent with the conception of the self yielded from his view on causation, and that conception is at odds with an exceedingly individualistic conception. ${ }^{59}$

A related conclusion can be drawn with respect to the prior discussion of Hobbes's determinism in Leviathan, namely: the self continually changes because of a complex array of external and internal causal chains that are perpetually at play; there is no atomistic self that persists through the perpetual flux. ${ }^{60}$ This prevents the self from being detached from the people, institutions, practices, and so on, which form (via causal chains) one's internal constitution. Indeed, for Hobbes, there is no act in one's life that is not in some way connected to other things. Frost draws out this sentiment as follows:

According to [... Hobbes's] materialism, a subject's sense of self, and his or her patterns of desire and thinking, are not ever wholly his or her own. They are not autogenetic, autonomic phenomena. Rather, individuals' subjective self-identity, their thoughts, and their desires are constituted and modified by their ongoing encounter and engagement with one another and with the world. ${ }^{61}$

In other words, Hobbesian causation ties the self to others (and to other externalities) fundamentally, and the self would be inconceivable without such ties. Frost rightly contrasts this conception of the self with "the philosophically conjured rational wills who compose Kant's postulated moral community."62 Unlike the liberal tradition represented by Kant and Rawls (and the tradition in which Hobbes's political theory is sometimes placed without context), then, the interaction between persons in Hobbes's civil society and state of nature are not abstract dealings that are driven by "the intellectual manipulation and consideration of rational principle." ${ }^{63}$ Rather, they are driven by externalities to which the self is inextricably intertwined through innumerable causal chains.

A similar picture is available when returning to De Corpore, where Hobbes describes cause and effect as continuous interaction between agents and patients. Importantly, he says that when an agent and patient are not contiguous (i.e., when another body lies between them), the body between the agent and patient "is then itself both an agent and a patient; an agent in respect of the body next after it, upon 
which it works, and a patient in respect of the body next before it, from which it suffers." ${ }^{\prime 4}$ Frost seizes upon this passage to make the point that for Hobbes specific acts are not to be viewed "in terms of their immediate causes and immediate intended effects but rather in terms of the chains of causal antecedents as well as the 'long chaynes of consequences' that continue to unfold after a particular act can be said to have taken place." ${ }^{15}$ Lisa Sarasohn has taken a similar position, arguing that for Hobbes "neither the 'animal spirits,' the brain, the soul, the appetite, nor the will have any original principle of motion. They are completely passive and act only in response to the impact of external agents." point is crucial: an "agent simpliciter" is inconceivable because an agent in the world is also a patient in the world, and each is influenced continuously by a vast array of causal chains. ${ }^{67}$

The long and short of it is that the liberal conception of a bare self that imposes its pure will on the world seems inconceivable for Hobbes because all bodies act necessarily as both agents and patients via complex causal chains. Another way to put the point is in terms of interconnectedness. One's self forms a part of a collective and one's self is unavoidably interconnected with the various other parts of the collective in which one finds oneself. ${ }^{68}$ This means that for Hobbes the individual may not be thought of as forging a course through the world solitarily: The individual may "act only to the degree that the extant passive powers or social conditions allow." ${ }^{69}$ In other words, we are encumbered by the collective for better or for worse.

Again, then, we can see how Hobbes is closer to the positivist school of criminology that previously considered. Of course, this does not mean that all his connections to the classical school have suddenly vanished. The point is rather that his association with various theories of criminology should be more nuanced. The claim is not particularly controversial when considering how the positivist school began as an attempt to provide more "scientific" explanations of crime - including the many social and psychological forces that explain a person's path to crime. The positivist school had many infamous false starts, ${ }^{70}$ but consider just one of the movement's more lasting contributions: the so-called "Chicago School."

In the early 1920s, the burgeoning Department of Sociology at the University of Chicago began to view the city of Chicago as its "field" for the study of human relationships. ${ }^{71}$ One of the central issues on which the department focused was how social processes determined the extent to which racial and ethnic groups assimilated into society broadly. ${ }^{72}$ Somewhat related was the department's development of the idea of "human ecology," which reduced the city to distinct communities and cultures that developed around societal and other barriers. ${ }^{73}$ One of the key contributions of this work was the application of concentric zones to these ecological communities. This resulted in studies showing that delinquency rates declined as one moved from the city's center to the city's outlying zones. ${ }^{74}$ And this led to other studies regarding the nature and impact of living in a particular ecological area, including, for example, the different family types in different zones. ${ }^{75}$ In terms of methodology, "[e]cological studies consisted of making spot maps of Chicago for the place of occurrence of specific behaviors, including alcoholism, homicides, suicides, psychoses, and poverty, and then computing rates based on census data." ${ }^{\prime 6}$ The source of crime was thus external, not internal.

In other words, the result of the Chicago School was a series of theories focusing on how externalities (social organization) affected personality (or the what might be described as the "self"). Admittedly, the connections between this example of a positivist school of criminology and Hobbesian theory are only suggestive, as there has clearly been no attempt to provide a thorough accounting of every twist and turn of the Chicago (or any other) School. The point is rather to sketch some of the broad similarities that have hitherto gone unnoticed and that might be worth exploring in future work. And at least one conclusion is clear: Hobbes's political theory entails a more complex conception of the self than typically assumed, and that conception results in a more nuanced conclusion about how his political theory relates to criminological theory. The metaphysical underpinnings of both his natural and political philosophy downplay the notion of a purely individualistic conception of the self that is governed solely by volition, instead pointing to a more positivist theory of criminology

A final observation worth emphasizing is the ways that Hobbes's determinism is consistent with the liberal tradition - particularly with respect to criminal justice - despite the differences that have been noted. Rawlsian liberalism is a representative example. Rawls famously argued that one does not deserve one's starting place in society, nor one's good or bad character, because those things are determined by externalities over which one has no control. ${ }^{77}$ Although Rawls does not set this view against the backdrop of determinism explicitly, the similarity to Hobbes is unmistakable. In certain 
respects, Rawls's conception implies that every aspect of a person is determined by externalities, perhaps in a way similar to the causal chains that are crucial in determining the Hobbesian self. In his well-known critique of this view, Robert Nozick characterized the liberal conception of the self as follows: "This [Rawlsian] line of argument can succeed in blocking the introduction of a person's autonomous choices and actions (and their results) only by attributing everything noteworthy about the person completely to certain 'external' factors." 78 Although one may take issue with Nozick's critique of Rawlsian liberalism, it is uncontroversial to say that Rawlsian liberalism generally views one's natural attributes and starting place in society to be determined by externalities beyond the self.

In a sense, then, Rawls does provide a robust account of how social context influences the development of the liberal subject: Although the original position is a highly abstract device designed to represent a highly abstract conception of the self, Rawls rounds out this conception of the self (the output of the original position) by focusing closely on the myriad of external factors that are vital to the formation of the self. This means that Rawls's notion of desert is in many ways similar to Hobbes's, particularly in the context of criminal liability. For instance, Hobbes's view on punishment is informed by an understanding of the casual chains that lead to a particular crime. Hobbes acknowledges many circumstances that may mitigate one's liability under the law, and he even says that certain circumstances preclude one's obligation to obey the law, such that if an "accident [...] hath taken away the means to take notice of any particular Law [... then] that Law is no Law to him." 79 In short, Hobbes's casuist perspective is roughly analogous to a liberal conception of desert in that the causal chains and externalities that influence one's actions may mitigate one's responsibility ${ }^{80}$ In spite of their profound differences, then, it is of course important to acknowledge the many connections between the Hobbesian political tradition and certain aspects of the contemporary liberal tradition. This is particularly true of those connections that are found in the context of Hobbes's determinism, which lurks just beneath the surface of his political theory.

\section{Conclusion}

Hobbes bridges natural philosophy and political philosophy in the Leviathan, particularly with respect to determinism's role in connecting a person to externalities. This notion is reaffirmed in De Corpore, where Hobbes sets forth the relationship between agents and patients. However, less attention has been paid to how this relationship provides a more complex conception of the Hobbesian self than typically assumed. Hobbes's state of nature does not yield a conception of the self that is a bare subject from whom the multitude of external influences may be stripped. This means that Hobbes's conception of the self may be distinguished in new ways from liberal conceptions, especially the individualist strand of liberalism associated with many contemporary accounts. It further shows the novel ways that Hobbes's conception of the self is socially embedded, while retaining similarities to liberalism as it relates to desert and criminal justice. These points are supported by two central observations: First, Hobbes's determinism opposes a conception of the self from which one may detach all externalities because those externalities necessarily determine the will and what the self is at any given moment. Second, there is no stable conception of the self that persists because the externalities at play on a subject keep the self in a constant state of flux.

The result is a more nuanced conclusion about how Hobbes's metaphysical theory relates to criminological theory. There is no doubt that Hobbes retains a prominent place as a forerunner of the classical school, which relies upon the presumption that persons are rational, free, and self-interested. Many aspects of Hobbes's political philosophy lend clear support for this view, helping explain how the threat of punishment can deter criminal behavior in persons. However, the metaphysical underpinnings of both his natural and political philosophy clearly downplay the notion of a purely individualistic conception of the self that is governed solely by volition. Rather, a fuller picture of Hobbes's philosophy shows how a variety of social and psychological forces relate to one's actions including actions that lead to crime. Taking a step back, one can see how Hobbes's position on causation illuminates a more complex view of the self that is associated with positivist criminology. Indeed, his theory is especially prescient with respect to twentieth-century variants of positivism that focus upon the connections between social organization and personality. In a sense, then, modern criminological theory is indebted to Hobbes's focus upon the connections between externalities and the self - which perhaps illuminates new ways of viewing responsibility and accountability. 


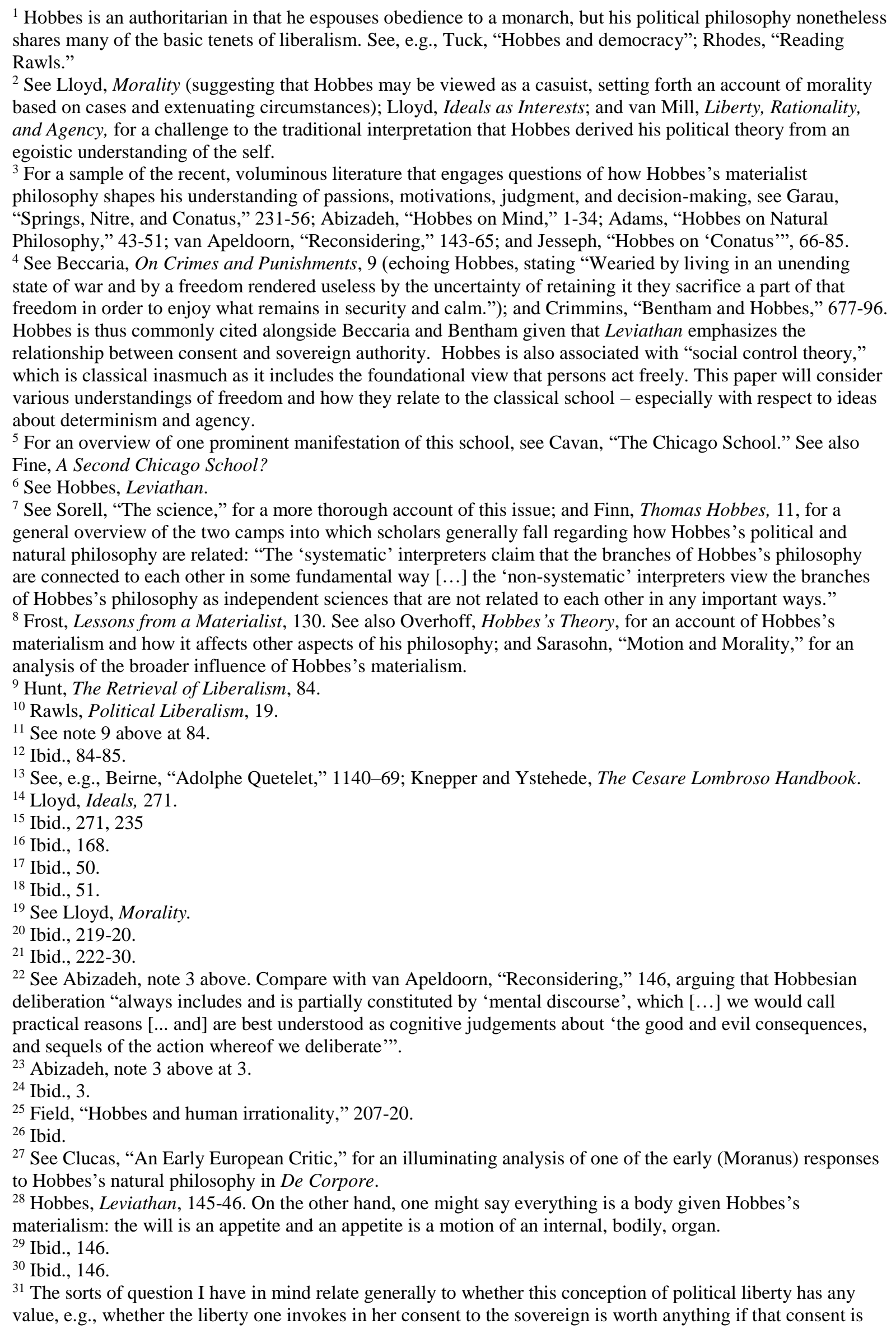


given out of fear. In the next few pages, I consider how Hobbes's conception of voluntary motion bolsters his conception of political liberty in that voluntary motion involves something internal in a subject, namely, the imagination. In other words, actions that are caused are necessary, and actions that are caused by one's will are free. This helps show the unique way in which Hobbes bridges natural philosophy to political philosophy.

${ }^{32}$ Hobbes, Leviathan, 146.

${ }^{33}$ Ibid., 147.

34 Ibid., 38.

${ }^{35}$ Ibid., 39. See Herbert, Thomas Hobbes: The Unity, for additional analysis on this point. Although Hobbes's terminology does not include static and dynamic, it seems reasonable to use such terms in regard to his notion of the self in light of his description of one's body, appetites, and aversions being in continual mutation.

${ }^{36}$ Hobbes, Leviathan, 253.

${ }^{37}$ Hobbes, De Corpore, 120-21.

${ }^{38}$ Ibid., 122. Power and act correspond to cause and effect for Hobbes: The accidents in an agent that constitute an efficient cause also constitute the power of the agent (active power), and the accidents in a patient that constitute the material cause constitute the power of the patient (passive power); efficient and material causes (entire causes) relate to effects already produced, while active and passive powers (plenary powers) relate to effects that have yet to be produced. Ibid., 127-28.

${ }^{39}$ Ibid., 123.

${ }^{40}$ Of course, Hobbes's position perhaps leads to other issues that many would find problematic. For example, when Hobbes says, "this proposition, what shall be, shall be, is as necessary a proposition as this, a man is a man," he is acutely aware of the question regarding whether future things (contingents) are necessary. Ibid., 130. He responds by arguing - as he must - that all future propositions are indeed necessarily true or necessarily false, though we think of them as contingent because we do not know whether they will be true or false. In other words, Hobbes provides an epistemic argument regarding the distinction between necessary and contingent causation. Although we do not know the truth of future propositions, they are determinately true or false.

Although this is the upshot of Hobbes's argument, it is beyond the scope of my argument.

${ }^{41}$ Gauthier, The Logic of Leviathan, 3.

${ }^{42}$ As discussed, there has been a great deal of debate in the literature regarding the extent to which Hobbes's philosophy is systematic in nature, as well as the way in which his political theory might fit into a system. Although I have provided some textual evidence regarding how Hobbes's natural and political philosophy are connected, I have assumed generally that Hobbes's project should be considered systematic to some degree.

${ }^{43}$ Hobbes, Leviathan, 127.

${ }^{44}$ Ibid., 89-90.

45 Ibid., 89.

${ }^{46}$ See Rhodes, note 1 above at 398, for the contrary view that persons in the state of nature know essentially nothing about themselves, including "their race, religion, nationality, level of education, and social or economic position."

${ }^{47}$ Hobbes, Leviathan, 65.

48 Ibid., 83.

${ }^{49}$ Ibid., 99.

${ }^{50}$ Overhoff, note 8 above at 14. The primary point that Overhoff is making here is how even Hobbes's early work (namely, The Elements of Law) was systematic in nature and demonstrated a scientific theory of the will. ${ }^{51}$ Rawls, A Theory of Justice, 10.

${ }^{52}$ Ibid., 11. In a footnote regarding the historical sources of social contract positions, Rawls states simply that, "For all of its greatness, Hobbes's Leviathan raises special problems." Ibid. n. 4. This does not mean that there are not obvious, crucial similarities between Rawls's and Hobbes's projects, as Rawls suggests elsewhere.

${ }^{53}$ Ibid., 11.

${ }^{54}$ Rawls's well-known account of the original position runs as follows: "No one knows his place in society, his class position or social status; nor does he know his fortune in the distribution of natural assets and abilities, his intelligence and strength, and the like. Nor, again, does anyone know his conception of the good, the particulars of his rational plan of life, or even the special features of his psychology such as his aversion to risk or liability to optimism or pessimism. More than this, I assume that the parties do not know the particular circumstances of their own society. That is, they do not know its economic or political situation, or the level of civilization and culture it has been able to achieve." Ibid., 118.

55 Ibid., 211.

${ }^{56}$ Tuck, note 1 above at 171-72.

${ }^{57}$ See, e.g., Rhodes, note 1 above at 398, in which it is argued that individuals in the state of nature are unaware of religion.

${ }^{58}$ It should at least be noted that it is unclear to what extent this would be a fair description of - and objection to - Rawls's conception of the self. In Part III of A Theory of Justice, for instance, Rawls seems to provide a fairly 
robust account of how social context influences the development of the liberal subject. See, e.g., Rawls, $A$ Theory of Justice, 456-64. So one might argue that while the original position is a highly abstract device designed to represent a highly abstract conception of the self, Rawls rounds out this conception of the self (the output of the original position) by focusing closely on the myriad of external factors that are vital to the formation of the self. I discuss this point further toward the end of the paper.

${ }^{59}$ Of course, while a device such as Rawls's “original position" is hypothetical and intended to provide a model of representation, one might argue that it is too detached from human externalities to justify the results it yields. Similarly, Rawls says that "the self is prior to the ends which are affirmed by it." Rawls, 491.

${ }^{60}$ This interpretation perhaps creates tension with Hobbes's position that only an agent can be free, as I discussed earlier. The tension may be tempered somewhat if we view it within the context of Hobbes's understanding of voluntary motion, i.e., voluntary motion proceeds from imagination - which only an agent may possess - but this imagination is nonetheless determined and continually changed by a confluence of externalities.

${ }^{61}$ Frost, note 8 above at 113.

${ }^{62}$ Ibid.

${ }^{63}$ Ibid.

${ }^{64}$ Hobbes, De Corpore, 121.

${ }^{65}$ Frost, note 8 above at 137.

${ }^{66}$ Sarasohn, note 8 above at 365 . More generally, Sarasohn argues that, “for Hobbes, the 'root-paradigm' of inertial motion analogically penetrated and transformed his understanding of both psychological behavior and political activity, and gave his social theories the status of cosmological realities." Ibid., 363.

${ }^{67}$ Frost, note 8 above at 137 . As discussed earlier, strictly speaking it would not be impossible to conceive of a Hobbesian self without conceiving of the particular external causal chains. One may be unaware of the specific causal chains, for example, but it seems problematic to say we can abstract away all such causal chains because those chains are fundamental in determining the will and the self, which would not persist as a stable, atomistic ideal.

${ }^{68}$ Ibid., 125. Frost connects this view to the establishment of a peaceful civil society as follows: "The idea is not that individuals should think of themselves as part of an integrated whole. Rather, it is that individuals should conceive of themselves as inevitably part of a collective whose constitutive relations have a significant bearing on the possibilities for peace, security, and prosperity that each individual can imagine and pursue." Ibid.

${ }^{69}$ Ibid., 155.

${ }^{70}$ See, e.g., the body of work by Cesare Lombroso, who claimed to have identified various congenital defects that explain criminality.

${ }^{71}$ Cavan, 411. See also Fine, A Second Chicago School?

72 Ibid.

${ }^{73}$ Ibid., 412.

${ }^{74}$ Ibid.

75 Ibid., 413.

76 Ibid., 415.

${ }^{77}$ In a lengthy and well-known passage, Rawls writes: "It is incorrect that individuals with great natural endowments and the superior character that has made their development possible have a right to a cooperative scheme that enables them to obtain even further benefits in ways that do not contribute to the advantages of others. We do not deserve our place in the distribution of native endowments, any more that we deserve our initial starting place in society. That we deserve the superior character that enables us to make the effort to cultivate our abilities is also problematic; for such character depends in good part upon fortunate family and social circumstances in early life for which we can claim no credit. The notion of desert does not apply here." Rawls, 89.

${ }^{78}$ Nozick, Anarchy, State, and Utopia, 214.

${ }^{79}$ Hobbes, Leviathan, 187.

${ }^{80}$ See Frost, note 8 above at $125-29$, for a discussion of this point. 


\section{Bibliography}

Abizadeh, Arash. "Hobbes on Mind: Practical Deliberation, Reasoning, and Language." Journal of the History of Philosophy 55 (2017): 1-34.

Adams, Marcus. "Hobbes on Natural Philosophy as 'True Physics' and Mixed Mathematics." Studies in History and Philosophy of Science 56 (2016): 43-51.

Beccaria, Cesare. On Crimes and Punishments and Other Writings. Edited by Richard Bellamy, Cambridge: Cambridge University Press, 1995.

Beirne, Piers. "Adolphe Quetelet and the Origins of Positivist Criminology.” American Journal of Sociology 92 , no. 5 (1987): 1140-69.

Cavan, Ruth Shonle. “The Chicago School of Sociology, 1918-1933.” Urban Life (1983).

Clucas, Stephen. “An Early European Critic of Hobbes’s De Corpore.” Hobbes Studies 30, no. 1 (2017).

Crimmins, James E. "Bentham and Hobbes: An Issue of Influence." Journal of the History of Ideas 63, no. 4 (2002).

Field, Sandra. "Hobbes and human irrationality." Global Discourse: An Interdisciplinary Journal of Current Affairs and Applied Contemporary Thought 5, no. 2 (2014): 207-20.

Fine, Gary Alan. A Second Chicago School?: The Development of a Postwar American Sociology. Chicago: University of Chicago Press, 1995.

Finn, Stephen J. Thomas Hobbes and the Politics of Natural Philosophy. London: Continuum International Publishing, 2004.

Frost, Samantha. Lessons from a Materialist Thinker. Stanford: Stanford University Press, 2008.

Garau, Rodolfo. "Springs, Nitre, and Conatus. The Role of the Heart in Hobbes's Physiology and Animal Locomotion.” British Journal for the History of Philosophy 24 (2016): 231-56.

Gauthier, David. The Logic of Leviathan. Oxford: Oxford University Press, 1969.

Herbert, Gary B. Thomas Hobbes: The Unity of Scientific and Moral Wisdom. Vancouver: University of British Columbia Press, 1989.

Hobbes, Thomas. De Corpore. In Molesworth, English Works, vol. I, 120-21.

Hobbes, Thomas. Leviathan. Cambridge: Cambridge University Press, 1991.

Hunt, Luke William. The Retrieval of Liberalism in Policing. New York: Oxford University Pres, 2019.

Jesseph, Douglas. "Hobbes on 'Conatus': A Study in the Foundations of Hobbesian Philosophy." Hobbes Studies 29 (2016): 66-85.

Knepper, Paul, and Ystehede, Per Jorgen. The Cesare Lombroso Handbook. Routledge, 2014.

Lloyd, S.A. Ideals as Interests in Hobbes's Leviathan. Cambridge: Cambridge University Press, 2003.

Lloyd, S.A. Morality in the Philosophy of Thomas Hobbes. Cambridge: Cambridge University Press, 2009.

Nozick, Robert. Anarchy, State, and Utopia. New York: Basic Books, 1974.

Overhoff, Jurgen. Hobbes 's Theory of the Will. Lanham: Rowman \& Littlefield, 2000. 
Rawls, John. Political Liberalism. New York: Columbia University Press, 2005.

Rawls, John. A Theory of Justice. Cambridge: Harvard University Press, 1999.

Rhodes, Rosamond. "Reading Rawls and Hearing Hobbes.” The Philosophical Forum 33, no. 4 (2002).

Sarasohn, Lisa T. "Motion and Morality: Pierre Gassendi, Thomas Hobbes and the Mechanical World-View." Journal of the History of Ideas 46, no. 3 (1985).

Sorell, Tom. "The science in Hobbes's politics.” In Perspectives on Thomas Hobbes, edited by G.A.J. Rogers \& Alan Ryan. Oxford: Clarendon Press, 1988.

Tuck, Richard. "Hobbes and democracy." In Rethinking the Foundations of Modern Political Thought, edited by Annabel Brett and James Tully. Cambridge: Cambridge University Press, 2006.

van Apeldoorn, Laurens. "Reconsidering Hobbes's Account of Practical Deliberation.” Hobbes Studies 25 (2012): 143-65.

van Mill, David. Liberty, Rationality, and Agency in Hobbes's Leviathan. Albany: State University of New York Press, 2001. 